\title{
Pengembangan RPP Model Discovery Learning Tema Daerah Tempat Tinggalku Pada Siswa Kelas IV Sekolah Dasar
}

\author{
Sindi Lestari, Rintis Rizkia Pangestika * (D), Titi Anjarini \\ Pendidikan Guru Sekolah Dasar, Fakultas Keguruan dan Ilmu Pendidikan, Universitas Muhammadiyah \\ Purworejo, Jl. K.H.A. Dahlan No. 3 \& 6 Purworejo, Jawa Tengah, Indonesia \\ *Corresponding author: rintis@umpwr.ac.id
}

Received: 1 March 2021; Accepted: 5 July 2021; Published: 23 August 2021

\begin{abstract}
Abstrak: Penelitian ini bertujuan untuk mengembangkan RPP model Discovery Learning tema Daerah Tempat Tinggalku pada siswa kelas IV SD Negeri Kliwonan yang meliputi: (1) mengetahui kelayakan RPP; (2) mengetahui keterlaksanaan pembelajaran; (3) mengetahui respon siswa terhadap pengembangan RPP. Jenis penelitian yang digunakan adalah penelitian pengembangan atau Research \& Development (R\&D) dengan model 4D (Four $D$ ) yang terdiri dari empat tahap, yaitu: define, design, develop, dan disseminate. Subjek penelitian ini adalah siswa-siswi kelas IV SD Negeri Kliwonan. Berdasarkan hasil analisis data yang diperoleh dalam penelitian ini menunjukkan kelayakan dengan hasil validasi ahli (RPP dan materi) diperoleh nilai rata-rata 3,28 dengan kriteria valid. Hasil validasi (praktisi) diperoleh nilai rata-rata 3,68 dengan kriteri sangat valid dan RPP yang dibuat efektif berdasarkan hasil tes hasil belajar siswa diperoleh nilai rata-rata 84,2 dengan persentase ketuntasan sebesar $87,7 \%$ dengan kriteria sangat efektif. Hasil pengamatan pengelolaan keterlaksanaan pembelajaran diperoleh nilai rata-rata 3,64 dengan kriteria terlaksana seluruhnya. Hasil lembar angket respon siswa diperoleh nilai rata-rata dengan persentase sebesar 94,4\% dengan kriteria sangat praktis. Berdasarkan hasil uji coba produk yang dilaksanakan, RPP model discovery learning tema Daerah Tempat Tinggalku pada siswa kelas IV SD Negeri Kliwonan telah memenuhi kelayakan (kriteria valid, praktis, dan efektif) dan keterlaksanaan pembelajaran serta respon siswa yang mencapai kriteria yang sangat baik.
\end{abstract}

\section{Kata Kunci: RPP, Discovery Learning, Siswa Sekolah Dasar}

\begin{abstract}
This study aims to develop lesson plan with discovery learning models with the theme "The Area Where I Live" in the fourth-grade students of Kliwonan Elementary School which includes: (1) Knowing the feasibility of the the lesson plan. (2) Knowing the implementation of learning. (3) Knowing the students' responses to the development of the lesson plan. The type of research used is Research \& Development $(R \& D)$ with the $4 D$ (Four D) model which consists of four stages, including: define, design, develop, and disseminate. The subjects of this study were fourth grade students of SD Negeri Kliwonan. Based on the results of data analysis obtained in this study shows the feasibility of expert validation results (lesson plan and material) obtained an average value of 3.28 with valid criteria. The results of the validation (practitioners) obtained an average value of 3.68 with very valid criteria and lesson plans made effective based on the results of student learning outcomes obtained an average value of 84.2 with a percentage of completeness of $87.7 \%$ with very effective criteria. The results of the observation of the implementation of learning management obtained an average value of 3.64 with the criteria being implemented entirely. The results of the student response questionnaire sheet obtained an average value of $94.4 \%$ with very practical criteria. Based on the results of the product trials carried out, the lesson plan with discovery learning model has met the eligibility (valid, practical, and effective criteria) and the implementation of learning and student responses have achieved very good criteria.
\end{abstract}

\section{Keywords: lesson plan, Discovery Learning, Elementary School Student}




\section{PENDAHULUAN}

Berdasarkan Permendikbud Nomor 22 Tahun 2016 tentang Standar Proses mendefinisikan Rencana Pelaksanaan Pembelajaran (RPP) sebagai "rencana kegiatan pembelajaran dengan adanya tatap muka untuk satu pertemuan atau lebih". Rencana Pelaksanaan Pembelajaran dikembangkan secara rinci dari suatu materi pokok atau tema tertentu yang mengacu pada silabus untuk mengarahkan kegiatan pembelajaran siswa dalam upaya mencapai Kompetensi Dasar (KD). Menurut Yansaputra \& Pangestika (2019) bahwa perangkat pembelajaran adalah suatu pola pembelajaran seperti roda berputar yang dilakukan secara terus menerus dan berulang. Perangkat pembelajaran berupa RPP perlu dilakukan pengembangan sehingga dapat membantu guru dalam proses pembelajaran dan memberikan pengalaman baru yang sesuai dengan kebutuhan siswa di sekolah.

Menurut Permendikbud Nomor 22 Tahun 2016 tentang Standar Proses RPP merupakan rencana kegiatan pembelajaran tatap muka untuk satu pertemuan atau lebih. RPP dikembangkan dari silabus untuk mengarahkan kegiatan pembelajaran siswa dalam upaya mencapai kompetensi dasar (KD). Kemudian, Isdisusilo dalam Hasriani (2017) menyatakan bahwa "Rencana Pelaksanaan Pembelajara (RPP) adalah rencana yang menggambarkan prosedur dan pengorganisasian pembelajaran untuk mencapai satu kompetensi dasar yang ditetapkan dalam standar isi dan telah dijabarkan dalam silabus. Rencana Pelaksanaan Pembelajaran (RPP) mengarahkan kegiatan belajar siswa dalam upaya pencapaian Kompetensi Dasar (KD)". Berdasarkan dua definisi RPP di atas dapat disimpulkan bahwa RPP adalah rancangan yang berisi rencana proses pembelajaran minimal untuk satu kali pertemuan, semua komponen yang ada di dalam RPP untuk memfasilitasi pencapaian KD.

Berdasarkan observasi yang dilakukan pada bulan Februari 2019 (saat pelaksanaan magang 2 di sekolah dasar) dan juga wawancara pada tanggal 22 Oktober 2019 di SD Negeri Kliwonan, guru terlihat malas membuat RPP ketika tidak diperiksa oleh pengawas, guru tidak membuat RPP, belum dapat mengembangkan RPP dan menggunakan RPP dari hasil download di internet, serta masih menggunakan RPP dengan model yang sama, tidak disesuaikan dengan kondisi atau kebutuhan siswa. Guru dalam menggunakan RPP masih menggunakan metode demonstrasi, ceramah, penugasan, dan tanya jawab, sedangkan pelaksanaan model pembelajarannya, guru dalam penerapan pembelajaran penemuan (discovery learning) kepada siswa belum optimal (karena bagi siswa model discovery learning adalah sebagai suatu model yang baru), karena biasanya guru hanya menggunakan model pembelajaran scientific atau lebih banyak menggunakan model ceramah. Oleh karena itu, untuk mencapai tujuan pembelajaran yang diharapkan, guru perlu mengembangkan RPP dengan model Discovery Learning, sehingga siswa belajar tidak hanya berpusat pada guru atau memperhatikan penjelasan dari guru, namun siswa juga bisa untuk mengeluarkan pendapat dan bisa menemukan ide baru dalam proses dan hasil belajar mereka.

Aktivitas siswa yang dilakukan selama proses pembelajaran seperti bertanya, memberikan tanggapan, dan sebagainya dapat menumbuhkan sikap aktif. Pada proses pembelajarannya, siswa akan menjadi pusat belajar sedangkan pendidik berperan sebagai pembimbing, yang akan memberikan arahan dalam kegiatan siswa menemukan konsep sendiri dari materi yang dipelajarinya. Hasil baik yang akan dimiliki oleh siswa yaitu memiliki daya ingat dan pemahaman yang lebih baik karena siswa mampu bertukar pengetahuan yang sudah dimilikinya, ini juga akan berdampak pada prestasi belajar siswa. Peningkatan prestasi belajar tersebut siswa dituntut untuk aktif mencari atau menemukan sendiri permasalahan yang diajukan guru, dan siswa juga dapat mengumpulkan konsep dan membuktikannya. Melalui hal itu siswa dapat memahami materi dan selalu diingat karena siswa melakukan praktik secara langsung. Menurut pendapat Yansaputra \& Pangestika (2018) bahwa perangkat pembelajaran dengan menggunakan model disvovery learning mampu meningkatkan hasil belajar siswa, sejalan dan sesuai dengan pendapat Kristin \& Rahayu (2016) yang menyatakan bahwa model discovery learning dapat meningkatkan hasil belajar (prestasi belajar siswa). 
Dapat disimpulkan bahwa model discovery learning merupakan model pembelajaran yang menuntut siswa untuk aktif mencari atau menemukan ide sendiri yang telah dipelajari, sehingga menemukan sesuatu yang baru yang membuat pembelajaran lebih bermakna. Berdasarkan dari pernyataan di atas, hasil observasi dan temuan kajian di atas, maka peneliti melakukan penelitian pengembangan dalam mengembangkan Rencana Pelaksanaan Pembelajaran (RPP) Model Discovery Learning Tema Daerah Tempat Tinggalku Pada Siswa Kelas IV SD Negeri Kliwonan.

\section{METODE PENELITIAN}

Produk yang dikembangkan dalam penelitian ini adalah rencana pelaksanaan pembelajaran (RPP) model discovery learning siswa kelas IV SD. Prosedur pengembangan dilakukan merujuk pada model pengembangan 4D (Four D). Model ini dikembangkan oleh Thiagarajan (Sutarti \& Irawan, 2017) yang terdiri atas empat tahap, yaitu: tahap pendefinisian (define), tahap perencanaan (design), tahap pengembangan (develop), dan tahap penyebaran (disseminate).

Pengembangan RPP dalam penelitian ini menggunakan model 4D yang disederhanakan. Penyederhanaan yang dilakukan adalah model hanya memuat tiga tahap, yaitu tahap pendefinisian (define), tahap perancangan (design), dan tahap pengembangan (development). Peneliti menyederhanakan model 4D yang dilakukan karena ruang lingkupnya terlalu luas dengan mengingat keterbatasan kemampuan peneliti. Pengembangan RPP dengan menyederhanakan model 4D menjadi 3D dapat diuraikan sebagai berikut.

Tahap pendefinisian (define) ini terdapat lima langkah pokok, antara lain: 1) Analisis ujung depan dilakukan dengan tujuan untuk mengetahui masalah dasar yang dihadapi dalam pembelajaran sehingga membutuhkan perangkat pembelajaran berupa RPP yang relevan. Masalah dasar yang diperoleh yaitu belum adanya RPP yang menerapkan model Discovery Learning dan guru belum pernah menyusun RPP dengan menerapkan model Discovery Learning.; 2) Analisis siswa yaitu mengetahui karakteristik siswa yang sesusai dengan rancangan dan pengembangan RPP. Karakteristik siswa yang diperoleh yaitu bahwa siswa lebih senang belajar secara langsung dan berkelompok. Jumlah siswa perempuan ada 5 (lima) siswa dan laki-laki juga 5 (lima) siswa; 3) Analisis tugas dilakukan untuk menganalisis tugas yang akan dilakukan oleh siswa selama proses pembelajaran. Peneliti menganalisis tugas-tugas siswa yang diberikan oleh guru, seperti LKS dan tugas kelompok; 4) Analisis konsep bertujuan untuk mengidentifikasi dan menyusun konsep tujuan pembelajaran. Tujuan pembelajaran dikonsep sesuai dengan kebutuhan karakteristik siswa dan model pembelajaran yang diterapkan yaitu Discovery Learning; dan 5) Perumusan tujuan pembelajaran bertujuan untuk pencapaian indikator hasil belajar sebagai dasar dalam menyusun RPP. Tujuan pembelajaran yang dirumuskan antara lain.

Pada tahap perancangan (design) RPP serta materi pembelajaran, lembar aktivitas siswa, dan lembar evaluasi siswa diperoleh hasil yang dinamakan dengan tahap I. Pada tahap ini terdapat beberapa langkah, antara lain: 1) Penyusunan tes acuan patokan, tes ini merupakan suatu alat ukur untuk mengetahui terjadinya perubahan tingkah laku pada diri siswa setelah kegiatan belajar mengajar (dilakukan di kegiatan akhir pembelajaran). 2) Pemilihan media yang sesuai dengan tujuan dan pelaksanaan pembelajaran, untuk menyampaikan materi pelajaran. 3) Pemilihan format, yaitu dapat mengkaji format-format perangkat yang sudah ada.

Tahap pengembangan (develop) dilakukan untuk menghasilkan perangkat pembelajaran (RPP) dan materi pembelajaran yang sudah direvisi berdasarkan masukan dari para validator ahli (praktisi). Tahap ini meliputi beberapa langkah, yaitu: 1) Validasi oleh para ahli (validator) diikuti dengan revisi dan memberikan masukan ataupun saran sebagai penyempurnaan tahap I, berikut, setelah direvisi maka diperoleh perangat (RPP dan materi) hasil validasi yang dinamakan dengan tahap II, 2) Uji coba terbatas yaitu perangkat (RPP dan materi) diujicobakan di kelas yang dilakukan bersifat terbatas yaitu hanya 5 siswa dengan 
kriteria siswa yang memiliki kemampuan kognitif tinggi, sedang, dan rendah. Hasil dari uji coba di lapangan dianalisis dan digunakan sebagai bahan pertimbangan RPP tahap II sehingga diperoleh perangkat RPP tahap vinal/hasil.

Pada tahap penyebaran (disseminate) peneliti tidak dilakukan karena ruang lingkupnya terlalu luas dengan keterbatasan kemampuan peneliti, sehingga peneliti memodifikasi, model yang dilakukan hanya memuat tiga tahap yaitu tahap pendefinisian (define), tahap perancangan (design), tahap pengembangan (develop).

\section{HASIL DAN PEMBAHASAN}

Hasil

Penelitian ini adalah penelitian pengembangan, sehingga hasil penelitian dan pengembangan yang telah dilakukan di SD Negeri Kliwonan, berupa pengembangan RPP (rencana pelaksanaan pembelajaran) berbasis penemuan terbimbing (discovery learning). Validitas merupakan langkah awal pada tahap pengembangan, (berupa RPP) yang telah dikembangkan. Hasil validasi pakar/ahli berupa nilai validasi, koreksi, masukan dan saran yang digunakan sebagai dasar untuk melakukan revisi dan penyempurnaan RPP. Berdasarkan deskripsi hasil penelitian yang telah diuraikan pada hasil penelitian sebelumnya, pengembangan RPP diperoleh pembelajaran dengan menggunakan model penemuan terbimbing (discovery learning) berdasarkan model pengembangan 4D (four $D$ ) melalui tahapan-tahapan berikut: define (pendefinisian), design (perancangan), develop (pengembangan), dan disseminate (penyebaran). Hasil dari pengembangan RPP akan dilakukan uji kevalidan, kepraktisan, dan keefektifan. Hasil pengembangan pada tahap-tahap tersebut dideskripsikan sebagai berikut.

Berdasarkan dari hasil penelitian pengembangan RPP, terdapat beberapa kelebihan dan kekurangan. Kelebihan dari hasil penelitian adalah membantu menumbuhkan minat belajar siswa (siswa bisa berpendapat di dalam pembelajaran dengan penuh percaya diri) dan membantu memudahkan guru dalam pengambilan nilai. Sedangkan kekurangan dari hasil penelitian adalah penelitian dilakukan dengan jumlah siswa yang terbatas, dan penelitian juga berlangsung di rumah bukan di sekolah, sehingga di dalam proses pembelajaran berlangsung siswa kelihatannya tidak aktif, dikarenakan kondisi pandemi Covid 19.

Tahap akhir pada penelitian ini adalah pengembangan (develop). Pada tahap ini dilakukan dengan melalui dua tahap yaitu validasi dan uji coba. Pada tahap validasi produk yang telah disusun di validasi oleh validator dan diperoleh validasi hingga mencapai kriteria minimal valid seperti berikut: hasil analisis validasi perangkat antara lain lembar validasi RPP, validasi materi pembelajaran, dan validasi praktisi.

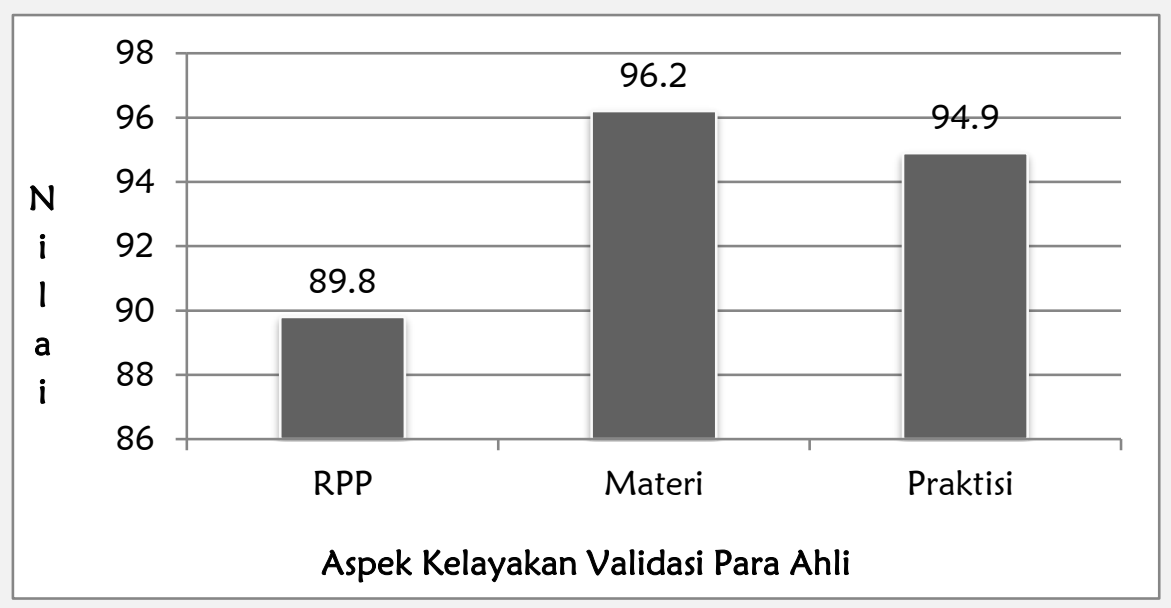

Gambar 1. Hasil Validasi Instrumen Model Discovery Learning 
Berdasarkan hasil dari lembar validasi RPP oleh validator tahap II diperoleh dengan rata-rata 3,41 dengan kriteria "valid". Validasi ahli tahap II diperoleh dengan rata-rata 3,68 yaitu dengan kriteria "sangat valid", sehingga hasil reliabilitas RPP mencapai 89,8\%. Hasil dari lembar validasi ahli materi pembelajaran tahap II diperoleh dengan rata-rata 3,11 yaitu dengan kriteria "valid", sehingga hasil reliabilitas materi mencapai 96,2\%. Hasil dari lembar validasi (praktisi) tahap II diperoleh dengan rata-rata 3,87 yaitu dengan kriteria "sangat valid (sangat praktis)", sehingga hasil reliabilitas praktisi mencapai 94,9\%. Berdasarkan hasil dari masing-masing validasi tersebut menunjukkan bahwa RPP dan materi pembelajaran yang telah dikembangkan sesuai dengan aspek pengembangan RPP dengan menggunakan model penemuan terbimbing (discovery learning).

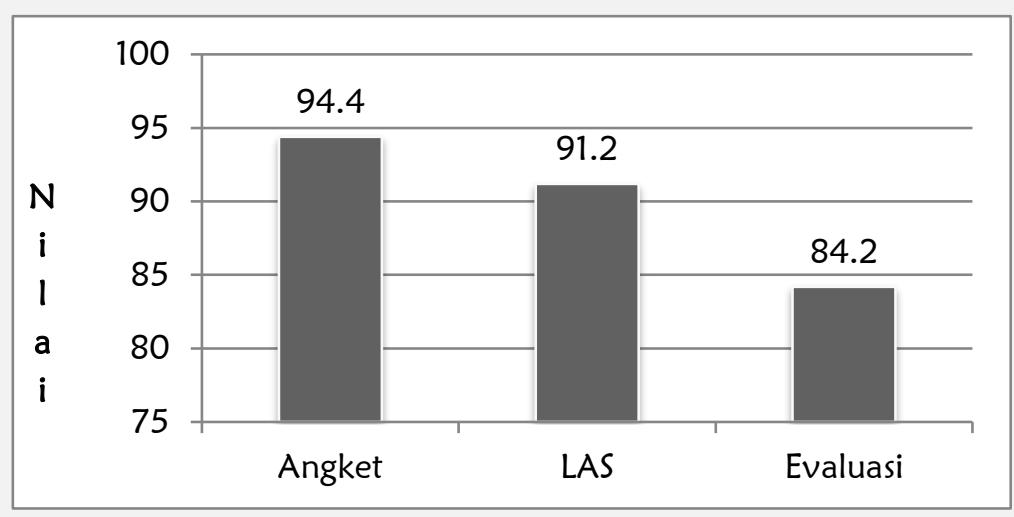

Diagram 2. Hasil Respon Siswa

Selanjutnya berdasarkan kriteria kepraktisan hasil dari hasil uji coba, siswa memberikan respon berupa angket respon siswa dilakuan di akhir pembelajaran berlangsung. Angket respon siswa diperoleh dengan rata-rata total 94,4\% dengan kriteria "sangat praktis" sehingga dapat disimpulkan bahwa sebagian besar siswa memberikan respon yang baik (positif) dan telah mencapai kriteria kepraktisan terhadap penggunaan RPP model penemuan terbimbing (discovery learning) yang telah dilaksanakan pada uji coba pembelajaran berlangsung. Berdasarkan kriteria keefektifan hasil dari hasil uji coba, diperoleh hasil tes belajar siswa dan hasil pengelolaan keterlaksanaan pembelajaaran. Hasil tes belajar siswa diperoleh dengan kriteria ketuntasan KKM minimal mencapai nilai 75, persentase ketuntasan hasil tes belajar siswa diperoleh $87,7 \%$ dalam kategori "tinggi". Pada tabel kriteria tingkat keefektifan pelaksanaan pembelajaran menunjukkan bahawa RPP memiliki persentase keterlaksanaan yang sangat baik sehingga data yang diperoleh dapat dikatakan efektif.

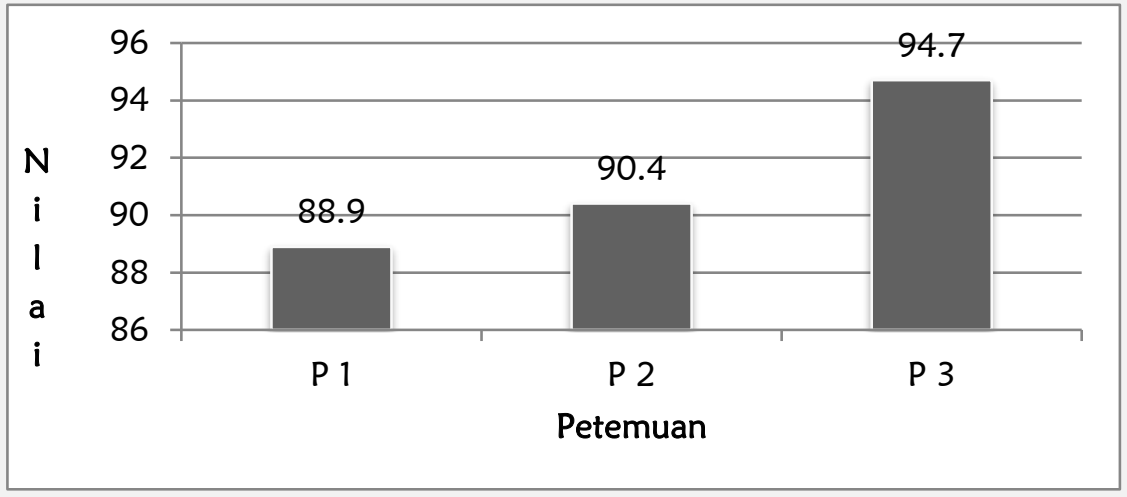

Diagram 3. Keterlaksanaan Pembelajaran 


\section{Pembahasan}

Berdasarkan dari pengembangan RPP, terdapat beberapa kelebihan dan kekurangan. Kelebihan dari hasil penelitian adalah membantu menumbuhkan minat belajar siswa (siswa bisa berpendapat di dalam pembelajaran dengan penuh percaya diri) dan membantu memudahkan guru dalam pengambilan nilai. Sedangkan kekurangan dari hasil penelitian adalah penelitian dilakukan dengan jumlah siswa yang terbatas, dan penelitian juga berlangsung di rumah bukan di sekolah, sehingga di dalam pembelajaran berlangsung siswa kelihatannya tidak aktif di dalam proses pembelajaran berlangsung.

Berdasarkan dari hasil uraian penelitian di atas, sejalan dengan pendapat Fitri dalam Irmawati et al. (2019) bahwa semakin tinggi nilai validitas maka semakin valid data yang diperoleh. Menurut pendapat Ramadhani dalam Irmawati, et al. (2019) bahwa perangkat pembelajaran (RPP) dikatakan praktis jika angket respon siswa yang diperoleh berada dalam kriteria praktis, selanjutnya dalam penelitian Rahman dalam Irmawati, et al. (2019) dapat dikatakan efektif ketika semua aspek atau indikator dalam keterlaksanaan pembelajaran tercapai dengan minimal baik. Sehingga dapat disimpulkan bahwa RPP pembelajaran yang dikembangkan memiliki kualitas kevalidan, kepraktisan, dan keefektifan.

Sejalan dengan Kementrian pendidikan dan kebudayaan direktorat jenderal pendidikan dasar dan menengah, direktorat pembinaan sekolah dasar tahun (2016) terbukti bahwa kelebihan dari pembelajaran discovery learning dapat membantu siswa untuk memperbaiki dan meningkatkan keterampilan dengan melibatkan imajinasi siswa dan menghilangkan sifat keraguan siswa.

\section{KESIMPULAN}

Berdasarkan hasil penelitian dan pembahasan dari pengembangan RPP model discovery learning, dapat diambil simpulan sebagai berikut. Pada penelitian pengembangan ini, diperoleh RPP model discovery learning yang mencapai kualitas kelayakan meliputi: kevalidan dan keefektifan hasil belajar. Kualitas kevalidan berdasarkan hasil validasi perangkat pembelajaran berupa RPP di tahap final diperoleh kriteria kevalidan yaitu "sangat valid"; tahap final hasil validasi materi pembelajaran diperoleh kriteria kevalidan yaitu "valid" dan tahap final hasil validasi (praktisi) diperoleh dengan kriteria kevalidan yaitu "sangat valid". Kualitas keefektifan lembar aktivitas siswa dalam proses pembelajaran berlangsung dengan kriteria sangat baik, dapat diketahui bahwa hasil perhitungan tes kemampuan hasil belajar siswa menunjukkan bahwa sudah melampaui kriteria minimal ketuntasan. Kemudian, RPP yang dikembangkan memiliki persentase ketuntasan yang sangat baik sehingga data hasil yang diperoleh dapat dikatakan efektif.

Hasil keterlaksanaan pembelajaran diperoleh berdasarkan hasil pengamatan pengolahan keterlaksanaan pembelajaran yang dilakukan oleh guru. Diketahui bahwa keterlaksanaan perangkat pembelajaran menunjukkan semua indikator yang diamati pada keterlaksanaan perangkat pembelajaran model penemuan terbimbing (discovery learning) dalam pembelajaran dalam kriteria sangat baik yaitu dengan kriteria "terlaksana seluruhnya", yang menunjukkan bahwa kemampuan guru (peneliti) dalam mengelola pembelajaran sudah sesuai yang diharapkan. Hasil respon siswa diperoleh berdasarkan hasil lembar angket respon siswa dengan kriteria "sangat praktis". Sehingga validasi tersebut menunjukkan bahwa data yang diperoleh dikatakan mencapai kualitas kepraktisan.

\section{UCAPAN TERIMA KASIH}

Penulis mengucapkan terimakasih kepada para pembimbing dan Universitas Muhammadiyah Purworejjo yang telah mendukung penelitian pengambangan dan publikasi ini. 


\section{DAFTAR PUSTAKA}

Arikunto. (2010). Prosedur Penelitian Suatu Pendekatan Praktik. Rineka Cipta: Jakarta.

Hasriani, H. (2017). Pengembangan Perangkat Pembelajaran Matematika Berbasis Penemuan Terbimbing (Discovery Learning) pada Pokok Bahasan Bangun Datar (Segiempat dan Segitiga) Kelas VII SMP Negeri 1 Sungguminasa Kabupaten Gowa (Undergraduate Thesis, Universitas Islam Negeri Alauddin Makassar).

Irmawati, M., Rukli, R., \& Baharullah, B. (2019). Pengembangan Perangkat Pembelajaran Matematika Menggunakan Metode Discovery Learning Berbasis GRANDER di Sekolah Dasar. Edumaspul: Jurnal Pendidikan, 3(2), 127-139.

Kristin, F., \& Rahayu, D. (2016). Pengaruh penerapan model pembelajaran discovery learning terhadap hasil belajar IPS pada siswa kelas 4 SD. Scholaria: Jurnal Pendidikan Dan Kebudayaan, 6(1), 84-92.

Permendikbud Nomor 22 Tahun 2016. Standar Proses Rencana Pelaksanaan Pembelajaran $(R P P)$.

Prastowo, A. (2015). Menyusun Rencana Pelaksanaan Pembelajaran (RPP) Tematik Terpadu Implementasi Kurikulum 2013 Untuk SD/MI. Prenadamedia Group: Jakarta.

Revita, R. (2017). Validitas Perangkat Pembelajaran Matematika Berbasis Penemuan Terbimbing. Suska Journal of Mathemaics Education.

Sutarti, T., \& Irawan, E. (2017). Kiat sukses meraih hibah penelitian pengembangan. Deepublish.

Widoyoko, E. P. (2018). Teknik Penyusunan Instrumen Penelitian. Pustaka Belajar: Yogyakarta.

Yansaputra, G., Rizkia, R. P. (2018). Pemikiran Kritis Dapat Dibentuk Melalui Discovery Learning. Indonesian Journal of Primary Education, 2(2), 34-39.

Yansaputra, G., Rizkia, R. P. (2019). Pengembangan Perangkat Pembelajaran IPS dengan Model Problem Based Learning Berbantuan Peta Konsep Untuk Meningkatkan Kualitas Pembelajaran IPS SD. Jurnal Pendidikan Surya Edukasi (JPSE), 5(1), 58-68.

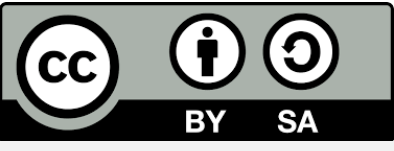

Copyright (c) 2021 by the authors. This work is licensed under a Creative Commons Attribution-ShareAlike 4.0 International License. 